Kohl: a Journal for Body and Gender Research

Vol. 6, No. 3 (Winter 2020)

\title{
In and/or/plus Out: Queering the Closet
}

Ahmed Ibrahim

\begin{abstract}
:
By enacting a reflexive return to our initial encounters with the ambiguous and multivalenced potential offered by queerness, I locate and piece together the traces of an always already lost/forcibly disappeared network that is constantly unfolding nonetheless. Taken together, these individual/ized encounters form structures of queer knowing, moving, and feeling that counter this individualization, which I argue is an integral part of the repertoire of techniques designed to foreclose the potential of a queer collective. It is with this in mind that I posit what I call authoritarian heterosexuality as a particular and particularly potent political regime, one that is entangled in colonial legacies and local sedimentations that inform the contemporary Egyptian state's attitudes towards queers specifically, and towards its citizenry more broadly. And by using this affective material as my entry point into an analysis of what queer might really mean here, I am able to reveal the traces of this violating constitution. Put differently, by engaging in a structural analysis of diverse articulations and experiences of queerness, I am simultaneously engaging in an analysis of the ways in which authoritarian regimes, in their efforts to eradicate queerness, end up producing it along lines that are perhaps illegible when read with the optic of traditional queer theory. To this end, I will be foregrounding my analysis in "the closet" as both a material artifact and disciplinary technology of this heterosexist regime that works to impress a damaging sense of individualism in subjects, as well as a site of potential for queers to collectivize, once the inconsistencies and similarities between such designations as "in" and "out," "private" and "public," and "individual" and "collective" are parsed out.
\end{abstract}


in closets, under floorboards:

a legacy

i am tired of being denied

a network of voices

an ancestry

a collective - where or

an existence

when is my community?

some semblance of realness

to make recourse to

in closets, under floorboards

i am tired of listening

creaking and cracking

of understanding and making do

conspiring on corruption and

of trying to explain to you

halting the production

everything

the manufacturing of a history

i am left absolutely

of meaning and ideology

nothing

no history, no memory

rigorous enough to save me

an alien

and being national enemy

in my own living room

on the street, in the mirror

in the bathroom staring back at me

abhorrent

scurrying back to safety

a body

and every inch an injury

in closets, under floorboards

creaking and cracking

thank you for carrying me

corrupting and conspiring

against me - everything

for being all the proof $\mathrm{i}$ need

of a history unseen

of legacies pulsing and

no form, no substance

packed tightly

no ontological resistance

and even then, an insistence

producing inaudible harmonies

screaming fuck you

to crawl out, a persistence

to the binary

flowing from within me

an entire trajectory enfleshed in me 


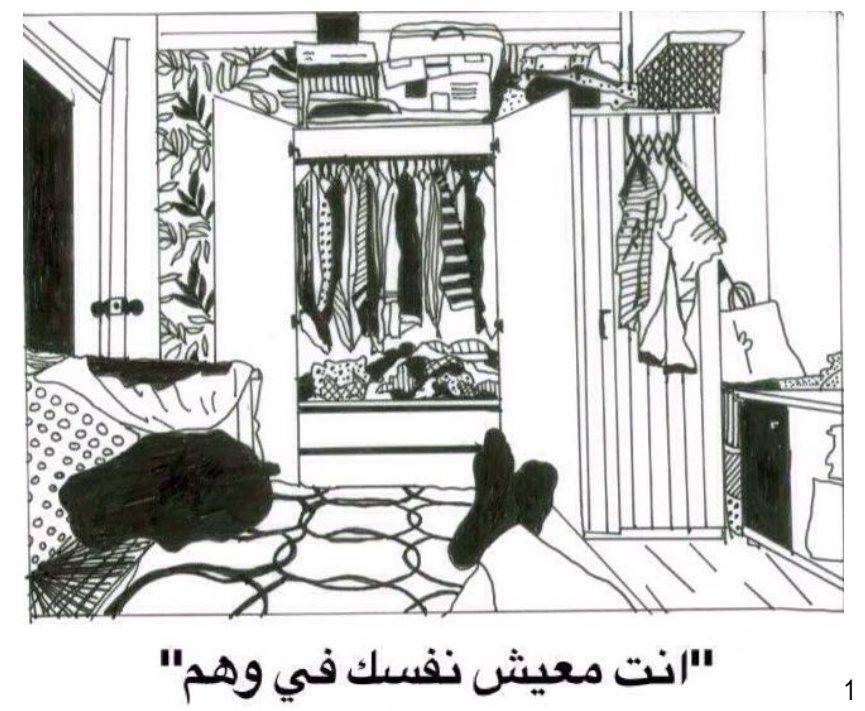

The summer I turned 21 was tumultuous to say the least. Even as I write this, admittedly in a much safer and healthier space, the prospect of revisiting, of digging up and relaying that experience is daunting. On the one hand, liberal commitments to include me have proven to be quite insidious. Unless I perform my intimate experiences of trauma and terror, I am illegible, illegitimate. On the other, it is those very intimacies that animate my life, and my performances of them will not only never be complete, they might also risk a complicity with those same imaginations that negate me. But where does one draw the line between this tedious and taxing rehearsal, a price many must pay under totalizing discourses of human rights, and acts of self-authorship that project oneself, as it were, into existence? Hesitating, I write nonetheless, in the spirit of that mode of authorship, and the connections it has formed between me and the few who have read my writing, as well as the potential connections that have yet to be formed, that are forming constantly. A politics of ephemeral presences.

A few days into the summer, my father confronts me about my perversions. And while this is not the first time, what made this confrontation different was that he had acquired proof. As I slept, my father went through my phone and found objective, undeniable evidence that his son was a خول 2 It had ceased to be a fleeting suspicion, and was now concretized as a testament to his failure as a father. What ensues is a series of physical and emotional altercations that leave me in bed for the majority of those three months. In the frenzy, he demands of me the telephone numbers of my co-conspirators and our alleged ringleader, who to him must have been the reason his easily-influenced son was dragged into this. I refuse and he smashes my phone to pieces. With nothing to lose, I attempt to, quite naively, stand my ground and fight him, convince him otherwise, appeal to his humanity first and then his rationality, but this spirit is short-lived and I eventually succumb to my plight. There was nothing I could do to change the situation I was in, and so I sank into my mattress and stewed for hours or days on end, staring into my closet.

During this time, my thoughts wander to and from queer liberation. I remember the repertoires of contention deployed by queers in the West in the name of making coming out political. Cocooned, I recall

\footnotetext{
${ }^{1}$ You are stuck living in an illusion of your own creation

2 Faggot
} 
romanticizing riots and public dissent and the refusal to go back into hiding. How many times had I looked to Stonewall for inspiration and longed for a revolution that would pave the way for generations thereafter to live without fear? I peek out from under the covers only to realize that the air outside is not any clearer, that it is thick with corruption, and that so many of us could barely breathe. With the future no longer in purview, it became clear that these were dreams not made for me. Illusions of escape that now stung too much to even entertain. Perpetually waiting for my life to "begin," it all crystalized that summer; that none of this was new, that it was in fact a plight predetermined, one which suspended me and people like me in these edge-of-existence experiences, saturated, steeped, and stuck. Rotting as I was, the closet staring back at me, a silent witness and testament, I think "when or where is my community?" There were many others like me, I knew that for sure, some friends, lovers, or strangers, but where were they? I began to imagine them in the buildings around me, or strewn across cities, in their own bedrooms, sinking and stewing, looking or hoping for me, as I was for them. I know that, had it not been for my privilege as an individual that has access to people with which and places wherein I can feel relatively safe, I would not be the person I am today. And this gratefulness and grief for "community" leads me to question the way in which these legacies of trauma are always necessarily felt in isolation. That there was only ever room for one in the closet so to speak, but that there were also more closets than I could count. Enough perhaps to make the claim that the particular violation we experience as queers in this part of the world could be construed as generational and historical trauma. We were and are everywhere and nowhere; pathologized and criminalized, struck out from archives, yet strewn across cities and states still, troubling institutions as we go. In our mutual expulsions from society par excellence then, what stood in the way of "community," as that which would/does offer alternative social, political, familial formations? "Communities" constructed around an impulse to live otherwise, however way that may look, and which, in so doing, counter the individualization of the closets in which we retreat, from which we emerge, and through which we might rearticulate a progressive politics together (Sullivan, 2003).

It seemed clear to me that it was precisely these lived experiences of violation and contestation that were the foundations upon which queer individuals negotiated senses of self and of belonging together against the backdrop of authoritarianism and state insecurity. What was interesting, however, was how this happened - specifically, what facilitated the transferability/communicability of these particular experiences between queers, and what that might tell us about what it means to lead "a queer life" here. Traditionally, this sort of questioning implicates multiple theoretical trajectories that have been occupied with similar questions for quite some time now, and that offer important insight into the ways in which subjectification is always already a sexed and racialized process (Wittig 1992; Fanon, 1970). In this regard then, I am also attempting here to unpack this process of subjectification, though to quite different ends. My aim is not merely to ask how a heterosexual economy produces "the figure of the nonheterosexual" or the queer subject, if that is a relevant designation, along specific lines, but more importantly to inquire after the conditions of possibility behind such a production in an authoritarian context like Egypt. I argue, however, that the conceptual tools at my disposal are limited by the fact of their incapacity and breakdown when taken out of the contexts in which they were designed. To say then that heterosexuality, for example, is compulsory is to completely gloss over the ways in which Western epistemes have contributed to the production of a stable "subject" that may voluntarily reject their heterosexualization. This presupposition of coherence is dangerous in several respects, most importantly for its failure to account for the inconsistencies integral to its own project of stabilizing, managing, and ordering subjects en masse. What becomes then of this model of subjectivity, even of queerness, when 
it is brought to bear on "subjects" that do not fit neatly within its confines? Indeed, they resist these fictions of coherence precisely because they are constituted at the intersections of multiple axes of violation that position them quite queerly vis-à-vis such constructions. What I offer here by way of an answer is no less inconsistent. And so, ordained by this breakdown of the conceptual strategies in which I have been trained to look for or at queerness, this article is an attempt to both work through such inconsistencies, as well as point to shared threads that offer spaces for a radical reconstitution when harnessed collectively. The now taken for granted optic of compulsory heterosexuality then not only has no room for these queered subjects, but it also reduces their complex relationship to the states that produce and position them as such, as well as the role this plays in statecraft.

And so, by enacting a reflexive return to our initial encounters with the ambiguous and multivalenced potential offered by queerness, I locate and piece together the traces of an always already lostforcibly disappeared network that is constantly unfolding nonetheless. The promise of queerness, calling out to the alienated subject. Taken together, these individual/ized encounters form structures of queer knowing, moving, and feeling that counter this individualization, which I argue is an integral part of the repertoire of techniques designed to foreclose the potential of a queer collective (Muñoz, 2011). It is with this in mind that I posit what I call authoritarian heterosexuality as a particular and particularly potent political regime, one that is entangled in colonial legacies and local sedimentations that inform the contemporary Egyptian state's attitudes towards queers specifically, and towards its citizenry more broadly.

I should note here that my thinking on these issues is indebted to a form of connectivity and commitment that I believe to be queer, or at least that ushers in those ambiguous and charged potentials that are part of its architecture. And much like I am indebted to my network of queer friends and family for giving me the space to explore and enact all that was foreclosed to me necessarily, it is in our relationships and the conversations we have that I looked for queerness. Contemporaneously charged by the chokehold of a state apparatus that leaves no room for us except "in the closet" or in its crosshairs, our specific and communal negotiations of our constant violation at the hands of this regime make up something of a roadmap to queerness. And by using this affective material as my entry point into an analysis of what queer might really mean here, I am able to reveal the traces of this violating constitution. Put differently, by engaging in a structural analysis of diverse articulations and experiences of queerness, I am simultaneously engaging in an analysis of the ways in which authoritarian regimes, in their efforts to eradicate queerness, end up producing it along lines that are perhaps illegible when read with the optic of traditional queer theory. To this end, I will be foregrounding my analysis in "the closet" as both a material artifact and disciplinary technology of this heterosexist regime that works to impress a damaging sense of individualism in subjects, as well as a site of potential for queers to collectivize, once the inconsistencies and similarities between such designations as "in" and "out," "private" and "public," and "individual" and "collective" are parsed out (Sullivan, 2003).

\section{Queering Method: Fixations, Limitations, and Openings}

I have been writing this paper, doing this work, for upwards of three years now, but in the last few months the arguments I have been attempting to make have changed considerably. In large part, this is because of the ongoing familial strife I am still struggling to maneuver, and which has animated, and at times 
completely halted, this process. Energized then by personal, political, and intellectual desires to make sense of my experiences, my stances have been quite reactionary, and justifiably so. Along the way, however, I became stuck in a solipsistic mode of thinking that limited me in several respects, and, quite ironically, mimicked the alienating individualization that I was so keen on unpacking. Inspired as I was by dialectical materialism, critical theory, phenomenology, queer theory, performance studies, and the intersections between them, I became walled off from other queers for whom experience was not a "potent site of inquiry," but rather a medium through which connections could be formed communally. I had developed a fixation with theory because it was a gateway of sorts to understanding my own experience, but no matter how much I read, I was still so incredibly frustrated. At the beginning stages of this research, my dysphoria had become utterly paralyzing, and my efforts to theorize it left me too anxious to write, thinking my experience was isolated and not enough to build an argument from. This culminated during the summer because it felt as though theory was useless to me then; indeed, it was. As I mention above, what mitigated this was the love and support I received from other queers; an affirmation no one else could offer me. I decided then that it would be counterintuitive to remain within the orbit of my experiences alone, and that engaging the people around me about the questions I had about subjectivity and sex would offer more by way of a nuanced analysis that was about us, for us, and by us. My research then became, or revealed itself as always having been a love letter to queerness, to other queers, to myself. I not only regained a sense of confidence in what I had to say as a result of these connections, but I also began to understand them as, in their own right, future-building projects that were decades in the making, perhaps even more. And it was this that inspired another fixation of mine, that of drawing my closet. This stemmed from a desire to untap what would be the paradigmatic experiences of a queer life, which both point to alternative spatiotemporal registers as well as make up the bedrock of structures of feeling that were at once universal and particular (Halberstam, 2005; Muñoz, 1999). In order to understand the ways in which queerness presented itself, called out to, began to unfold before and reoriented subjects, it seemed fruitful to engage in a series of practices of unlearning that were guided by questions that (though having changed multiple times throughout the research) were aimed at returning to what at the time seemed to me as a moment of initial deviance - our first encounters with queerness. The closet then, in its physicality as an artifact of a heterosexual regime which it itself naturalizes, its deployment as a barrier within oneself which produces the impression of privacy and interiority, and as a conceptual space to begin thinking from about the nature of such a charged subjectification, became the first place I looked for these structures of feeling.

With this in mind, I reached out to long-time interlocutors to ask what exactly "coming out" entailed, what it was that one "came out" to and where from, and what relevant distinctions occurred to them between "in" and "out" in that sense. As well as more casual conversations, I resorted to traditional semi-structured interviews, with an added exercise that asked the interlocutors to reflect visually on one or more of a series of prompts of the same nature. What I ended up with was more material than I knew what to do with on the one hand, as well as the breakdown of the conceptual framework I had begun this endeavor with. The visual material in particular was illuminating because it both allowed the participant (and, by extension, me) access to a memory or feeling that was fleeting and difficult to articulate, while also making the identification of relevant structures of feeling much easier due to the recurrence of themes and visual motifs which pointed to fragmentation and individualization as important threads that tie these diverse experiences together. There remains much more to be said of the visual material on its own, but for the purposes of this article, I have used the pieces in conversation with the accompanying interviews. All the 
material, however, whether visual, written, or recorded, was analyzed with the respective participant, and revisited at each stage of the process.

As a final comment on my methodology, I should note that though the interlocutors with whom I worked on this research are relatively similar in terms of class and racial backgrounds, they are diverse in terms of their attachments to queerness, their positions as sexed subjects, as well as their political aspirations - some of which highlight significant tensions facing queer activism historically as well as in the contemporary. Similarly, while our social/economic/geographic proximity of course facilitated this transferability I am interested in, I am weary of making any sweeping generalizations about a queerness that transcends class and racial boundaries. And though I had intended to reach out to individuals outside of my pool of long-time interlocutors and collaborators, I was subject to familial constraints that made this difficult. My intention, however, is neither to present a comprehensive view of queer life in Egypt, nor even of the interlocuters' lives. It is rather to locate those always already forcibly disappeared networks in the making that connect queers here, and by piecing together these fragments of individual and subjective experiences, present a potential that can be directed and channeled collectively. By pointing to these structures of feeling, by no means complete or static, my aim, again, is to nod to queerness as opposed to capture it.

\section{Queer Here?: Authoritarian Heterosexuality and the Nation}

As intimated above, the guiding impulse behind this research has been a desire to see my experiences given their due weight as worthy sites of scholarly inquiry, and not as a curious and tragic addition to what would be a catalogue of gayness around the world. Indeed both the practice of cataloguing, and the production of categories integral to such a project, have been critiqued to no end for the ways in which they flatten difference under universalisms that elide the materialities of race and class that are both inextricable from and constitutive of queer experiences in this part of the world (Muñoz, 1999; Rao, 2014). However, this imperative is nonetheless relevant to any analysis of sexed and gendered life, particularly in the SWANA region. This is partially due to the continued commitment many queers still have to global discourses of LGBT rights, one that, in significant ways, shapes their attachments to self and state, as well as their political imaginations of what a liberatory future might look like and where it might take root. Moreover, such discourses are also relevant for the reactions they induce on the part of the Egyptian state. And while it is not within the scope of this article to give an exhaustive history of the politics and problematics of LGBT discourses in Egypt, it is important to give a brief sketch in order to contextualize the experiences I will introduce below.

A common feature amongst authoritarian state apparatuses has been the enforcement of emergency laws which, among other things, escalate particular offenses and the judicial processes associated with them to the level of "matters of national security." One consequence of this designation is the diagnosing and sensationalizing of an alleged social/moral ill, thus justifying the especially violent means with which it is treated. The Queen Boat arrests and the ensuing moral panic of 2001 were the first heavily publicized incidence of legal persecution of queers in the country, sparking much controversy within and outside of its borders. Pratt (2007) has argued that such an event was purposefully utilized by the state in order to produce a spectacle that would, on the one hand, divert a disillusioned and demoralized public from the 
rapidly worsening economic recession, and on the other, assert an image of masculinized national integrity/sovereignty in the face of encroaching imperial threat and shifting political economies of gender. This anxiety over an untouched national essence is perhaps also a staple amongst authoritarian postcolonies, paradoxically missing the irony in holding onto an idealized essentialism when it is precisely essentialized renderings that have and continue to plague the region (AbuKhalil, 1997). Even more paradoxical, the efforts to define Egyptian-ness with all that is masculine, heterosexual, Islamic, and when it is useful Arab, and against the western homosexual imperial agenda, simultaneously resulted in a discursive explosion in the public sphere. Now, the state had officially recognized the existence of "homosexual perverts," albeit only to eradicate them. The legacy of the خول as national enemy has continued with several minor incidents which peaked once again with the Mashrou' Leila arrests in 2017, still the largest campaign of witch hunts the country has seen to date. What all these incidents share in common is the "'[performance of]' a discourse of national security through which national sovereignty was (re)produced and political order was maintained," using the very bodies of predominantly gay men and transwomen as fodder for this image (Pratt, 2007, p. 129). Two days after the concert, the raids in full force, I crumble under the weight of a world that has no room for me and find myself running through the streets frantically crying, convinced I am being followed, and not sure whether I should lead whomever they are to where I live. I somehow make it to my room and try my best to sit still and let what I later realized was a panic attack subside. My sister finds me and I don't know how to explain to her the magnitude of my fear. Through tears, she tells me that I need to lay low because it was not safe here. How could I tell her that I knew that too well, that I had learned from older queers in my circle what to do during raids to keep myself safe, but that I was still too paralyzed by fear? The violence in the air was and is still palpable, and threats of forced disappearance, torture, harassment, and social, economic, and/or religious ostracism/disenfranchisement are active considerations in the minds of queers, whether or not there is an ongoing raid.

In this sense then, terms like "gay" are not only dangerous for queers to adopt or rally under, since they align them with American conspiracies to infiltrate and undermine Egyptian authority, immortalized in the image of the unwavering patriarch. They also fail to encompass the full range of experiences that animate the lives of those that have queer(ed) attachments to sex and gender, and thus to nation. Experiences of violation/constitution that are not, to use Mikdashi and Puar's (2016, p. 219) framing, "exceptional in these sociopolitical spaces: [they are] additional precisely because war, genocide, occupation, oppression, dictatorship, terrorism and killings are part of the everyday fabric of life for many people that live in the region." Such technologies of violence are then instrumental to the production and management of docile citizen-subjects. And while it has been argued that the most intimate tool of this violation is the category of sex and its parallel naturalization of the political and economic imperative to heterosexualize society, processes of state formation in the region require additional attention to the ways in which these colonial impositions have been "[embraced and resignified]," reworked and sedimented upon throughout history by local authorities (Wittig, 1992; Lugones, 2007; Rao, 2014, p. 177). Within such a charged context that positions queers at the interstice between non-being and being-target, caught in the crossfire of competing discourses of liberalism-as-liberation and obedience/loyalty to one's family, religion, and country, I agree with Rao that "homophobia" is "too narrow a term to encompass locally rooted affects that express hatred of the queer" (ibid.). In the remainder of this article, I will focus on the experiences produced by these affects and agendas in order to argue that the Egyptian state's strategies of authoritarian heterosexuality violate and queer subjects in constitutive ways. By exploring subjective 
articulations of the precarity of queer life here, I read these strategies as fundamentally fragmenting, producing subjects that are queer due to their positions vis-à-vis heterosexist constructions of self, nationIstate, and society. Similarly, by beginning from experiences of "the closet," I point to the mythologies sustaining such a construction, and which I argue are integral to its functioning as a barrier between queers that forecloses the potential of a radical intersubjectivity.

\section{Closeted Subjects: Coming Out or In?}

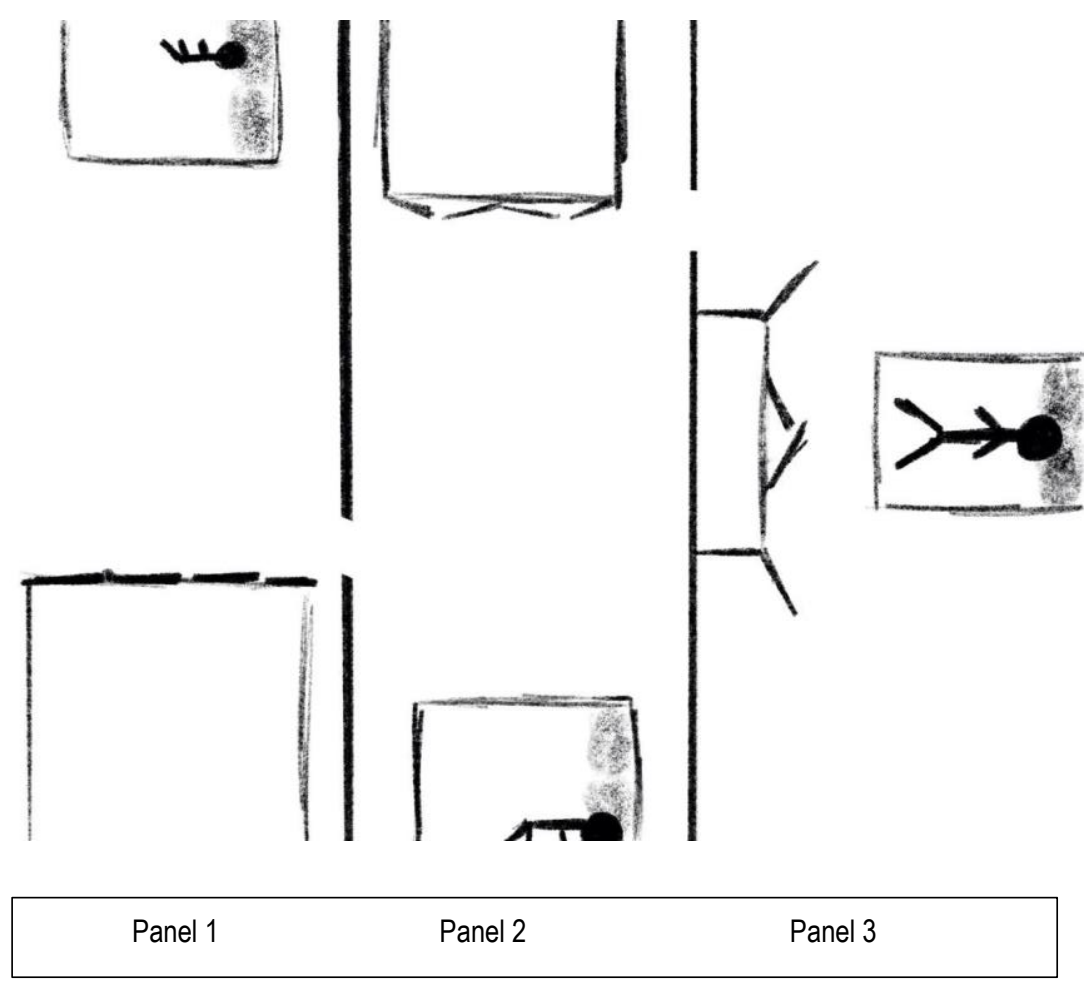

For Meem, manhood presented itself as "one big joke that [they weren't] in on." Saturated by heteronormativity, and confronted with the fact that those around them seemed to have no qualms with it, Meem describes to me the alienation they felt but struggled to name. "[lt was as though] I was picked from a crowd, pulled aside, and got a sticker put on my forehead." This experience of being marked is common amongst many of the individuals I worked with on this research, pointing to shared feelings of abjection amongst queers. The realization of/reconciliation with this mark, however, came in stages that Meem reflects on in the piece above, "l've lived in three houses." The piece emphasizes their position vis-à-vis their closet in three loosely bounded stages of their life. In the first panel, Meem is in the third grade, pressured by the weight of an emerging and vacuous lack from which they turn away, "because that wouldn't make mom and dad happy." The next panel depicts a critical juncture for Meem. Their closet was now "overflowing", and they could no longer turn away. Elaborating on this stage, Meem tells me about the strenuous activity of performing heteronormativity, which exacerbated an already overwhelming pressure they felt to change, or at least conceal what had become clear to them was an aberration (their queerness). Finally, in the last panel, Meem surrenders, "it wasn't like an 'I'm accepting myself coming out,' it was more of an 'I've been defeated and here's me declaring it." Meem remains ambivalent about this stage however, at times preferring to be innocuous, noting that they "seem to coexist pretty nicely" with their closet, yet still somehow caught between surrender and embrace. What is clear though is that, 
for Meem, the closet stood/stands in as their interior self to which they have a tenuous relationship. On the one hand, the illusion of privacy offered by the closet impresses upon Meem the feeling of an intimate interiority in which they can deposit their dirty little secret, while also producing the desire to "confess" all that is hidden there (Sullivan, 2003, p. 54). The closet naturalizes these machinations precisely because it is both a material artifact of a heterosexual economy, as well as a technology of sexed subjectification in its own right. If then the closet presupposes that which contains it (a heterosexual world), by that same token it also presupposes that which it must contain (a heterosexual subject). The realization of a mark and resultant internalization of a lack that Meem, as well as many queers experience, is perhaps then the moment at which the closet begins to creak open, revealing itself as a structuring force in the subject's life due to that subject's queerness vis-à-vis subjectivity par excellence.

\section{Living Up to Labels}

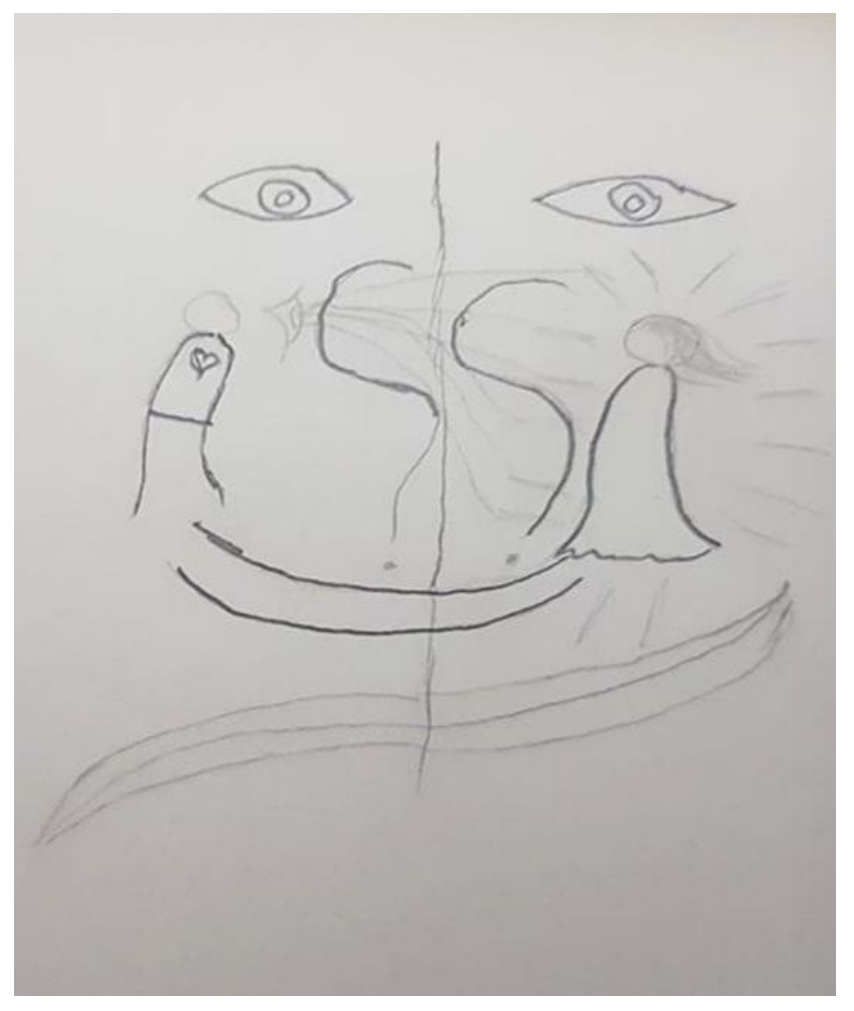

I began each interview by asking the participants how they would like to be referred to in this text and what additional information they felt that they wanted to share. This was partly because I was keen on avoiding issues of misrepresentation, particularly for this group of individuals whose very legibility and safety hinge on these discursive strategies. But it was also an attempt to probe these strategies and ask after how they have affected each participant's capacities for action, as well as their senses of self. With Aurora, this ended up being the majority of what we discussed. For her, the process of questioning her sexuality and gender came in stages, grounded in a felt knowledge that she was/is otherwise. Before arriving at the term "genderqueer," she tells me of the arduous struggle to find a perfect term to describe her experiences, one that was fraught with gatekeeping, paranoia, and shame. When I asked her to revisit her earliest memory of queerness, she gave me the above piece depicting her initially confusing yet quite affirming experience of an "other type of attraction to things gendered feminine." For her, 
performances of femininity called out to a latent and as of yet unexplored potential that she was "something other than a man .... ".." Calls such as these, however, became filtered through the language of LGBTQ identity, prompting Aurora to feel excluded on account of her non-normative patterns of sexual attraction and failure to adhere to rigid binaries of sexual or gendered self-definition. Compounding this isolation she felt from queers, her own queerness as well as her struggle with mental health continued to trouble her. Not only were LGBTQ identities too rigid to encompass the full range of her experiences, they also made her feel estranged from them on account of their western origin: "انا حتى مش مستو عب4 how to talk about my gender and sexuality from the perspective of an Arab." And though terms like "genderqueer," or simply "queer" presented her with the promise of a fluidity with which she could continue searching for what felt right, Aurora is still wary of identarian language altogether. She draws an interesting distinction between "identifying with something" or identity as the mathematical equality of variables ("I am equal to or like this"), which has been empowering for her in terms of her own self-definition, and the traditional liberal conception of identity or "identifying as something," which is automatically read as "playing pretend" ("I am not actually this"). For her, "[getting] stuck" in this second conception of identity inevitably leads to a fundamental estrangement from one's local context as well as one's own experiences by proxy, due to the entanglement of identity with the disciplinary practices enshrined it its architecture. She posits two forms of questioning of one's sex/sexuality/gender. The first is identitarian, or tied to the labor (ultimately futile) of proving one's "termness" to oneself and others, and which originates with the internalization of shame and self-loathing to the effect that one constantly questions their own validity: "was it real? .... همكن أكون asexual This harmful mode of questioning is reinforced externally as well as from other queers who practice forms of gatekeeping and policing of who gets to use what term and when. The second form of questioning emerges from the promise of queerness to allow an individual to engage in generative experimentation and pursuit. And while she is critical of identity, Aurora believes in the political imperative of coming out as a prerequisite for liberation, pointing to a major impasse in queer organizing in the region - the question of visibility.

\section{Wide Open, Closed Shut: The Double Function of The Closet}

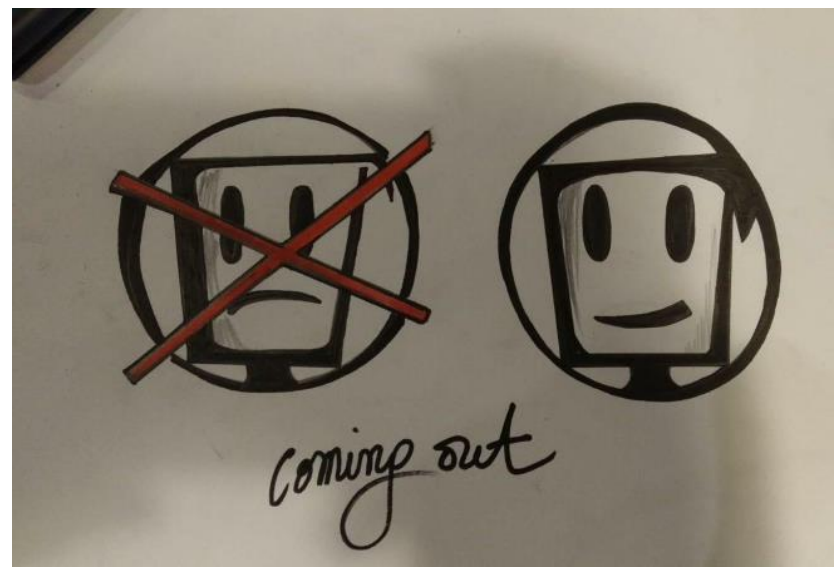

\footnotetext{
3 "This was the small space I had to discover more about myself"

4 "I can't fathom"

5 "Am I really Asexual? I could be lying"
} 
In order to parse out this impasse, I began to adjust my questions so that I could better understand the ways in which practices of making oneself or one's queerness visible/invisible complicate simple binarizations of in/out and docility/agency. It is important to add here that this particular problematic of when, if ever, to be visible, and what role visibility has in a progressive queer politics, if any, has different stakes for different constituents. Amir's formulations on the matter were interesting for me because they pointed me to the dual nature of closeting as at once asphyxiating and agential, depending in intensity on the subject. For them, the discourse of "coming out" as a moment of full disclosure is, in all regards, white; "there is no such thing as being completely out or in." Rather, queers in Egypt are "out" in some contexts, while not in others. This conception of relative outness allows Amir to posit "in" as a mode of hyperawareness of the way they are being read, telling me that they are most in when they are pandering to cis-normativity so as not to call attention to themself, whether on the street, at work, or with family members and others with whom they are not comfortable. In contrast, Amir describes an idealized outness that hinges on the absence of a filter on themself or the way they act or present, when/where there is no "codification" of their body and thus their sex/gender. In this way, coming out for Amir represented a process of realizing how much of themself they had to repress in order to be undetectable, مدقوقة لغاية جوا جزمني6 but then I let it come out." This coming out as gradual seeping out was aided by their group of queer friends; however, the naming of their queerness came later with the Mashrou' Leila arrests of 2017.

[during the arrests]

طبيعي أكون منضايقة، في ناس بيتقبض عليها

for existing. This sucks ... but why am I so personally affected by this? Why am I so outraged? At work,

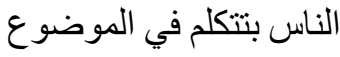

why is it that

انا حاسة اني مش قدرة اتنفس و بروج الحمام كل شويةج عشان اعبطو بنهار نفسبا؟7

At this moment, it became clear to them that they would never enjoy the peace of mind their non-queer counterparts did, and instead decided solidarity with their community was more important to them. And while they noted to me that the closet for them came to represent the feeling of being unsure of oneself, a self they struggle to fully accept, they concede to that same closet the potential to be harnessed for reasons beyond its mandate, so to speak. I agree with Amir here that, at a fundamental level, to lead a queer life in a postcolony like Egypt is to learn to be malleable, multifaceted, and resourceful. In other words, "learning through experience when to act, how, and where ... 8 in order to construct a representation of oneself. They maintain, however, that such a mode of existence is in fact quite difficult, often producing a feeling of "losing oneself in all the performances." This fragmentation is then mitigated and healed by what I refer to as queer connectivity, "لحد ما قابلتهم ماكنتش عارفة انا مين."

\footnotetext{
${ }^{6}$ Packed tightly under pressure

7 "I'm naturally upset, people are being arrested ... people at work are talking and I can't breathe, I keep going to the bathroom to cry and breakdown"

8 "By feeling it out and with experience"

9 "Until I met them, I didn't know who I was"
} 


\section{Answering Queerness' Call: Connectivity and Resignification}

In the earlier stages of the research that lead to this paper, I too was at an impasse of sorts with regards to how to get at what seemed to be an interstitial subjectivity that was common amongst queers here. Though looking specifically at trans subjectivities at the time, it seemed clear to me that this placed queers in a zone of non-being in the Fanonian sense (1970). The trans individual was then trapped in a failed subjectivity that could not transcend into the social, and was thus alienated. After engaging my queer and trans colleagues on this, however, it became clear that this conception of the liminality we experienced was too rigid. Even the experiential and visual material I gathered for this project resisted this determinism, and required a lot of revisiting and reconceptualizing together. In this section I read this material as examples of what for Butler would constitute a resignification. Indeed,

One does not stand at an instrumental distance from the terms by which one experiences violation. Occupied by such terms and yet occupying them oneself risks a complicity, a repetition, a relapse into injury, but it is also the occasion to work the mobilizing power of injury, of an interpellation one never chose. (1997, p. 383)

To repeat disloyally, however, is to respond affirmatively to that violation, to re-signify on one's own terms. And if we concede to queerness its capacity to call out to the alienated and heterosexualized queer, it becomes clear that this "subject" who is at the intersections of axes of violation, indeed confronted with and constituted by them, is not fully a subject at all. And though they cannot entirely reject "subjectivity" in this sense, they are nonetheless caught in its orbit, subjected by it. However, by responding to queerness as an alternative register of calls, queers push back at these confines by re-signifying the very media through which this subjection occurs. They perform/relate/appropriate/desire themselves queerly.

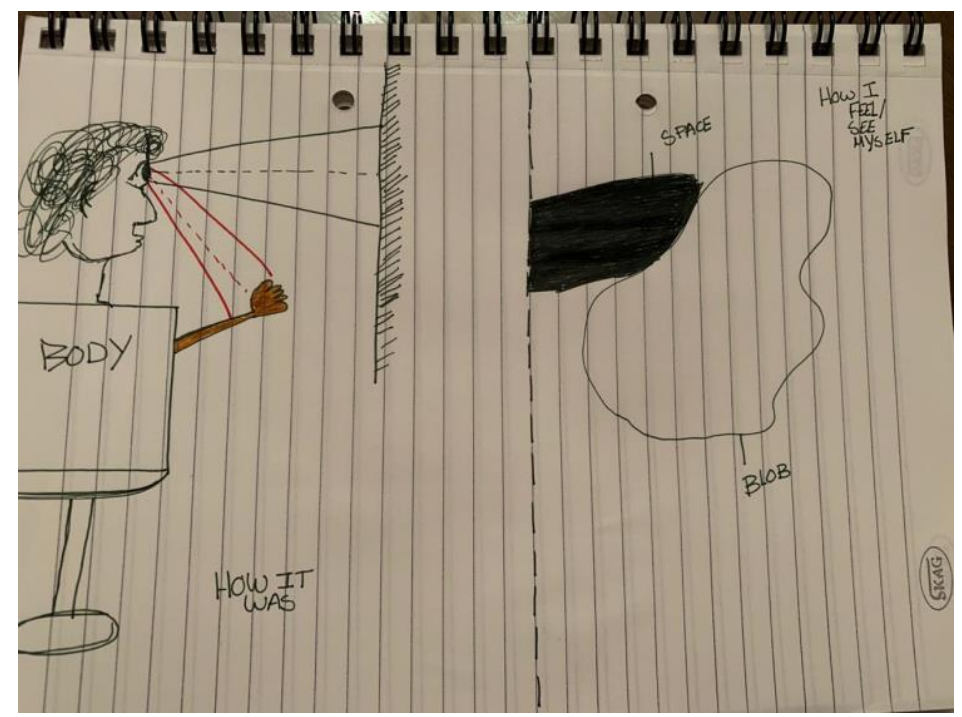

When I asked Nuun to draw their "coming out," they give me this two-paneled piece, "HOW IT WAS HOW I FEEL/SEE MYSELF." In the panel on the left, Nuun reflects on coming out as a process of selfrealization through confrontation with that which was "always there, in the background, but suppressed." 
For Nuun, the realization of their queerness was tied to a hyperawareness of the multiple gazes on their body. The drawing depicts a scene wherein Nuun is at a women's hair salon, their gaze locked at the reflection staring back at them, and "the contrast of the brownness [of their hand] in that space." To them, queerness was always already racialized, sexed, and gendered, and their sudden and violent hyperawareness of their body was only exacerbated by their struggle to perform along normative heterosexual lines, eventually culminating in the moment depicted where they decide to "just chop it [their hair] all off." And though Nuun tells me that, in retrospect, their desires to fashion themselves otherwise were, at the time, heavily influenced by "what [they] thought white people would look like when they chopped off their hair," they still look back on this act as profoundly agential for them. In itself, it instigated a process of "coming to terms" with themself by quite literally re-signifying their gendered, sexed, and racialized body in an affirmative gesture. In the panel on the right, Nuun is much more ambiguous about this process however, relaying to me that they "don't think [of themselves] as a physical entity or human being, but more as an amorphous blob suspended in space." This in part stems from the reflexivity of their hypervisibility due to their transgressions of heterogender norms, which in turn thwarts their desires to be innocuous. Nuun describes to me multiple encounters with uber drivers who, upon seeing them, cancel the trip and leave. And though they laugh to friends about this, the accumulation of instances like these continue to burden them. Nuun tells me that, for a long time, they sought refuge on the internet, saying "it sometimes feels like the only place where I actually exist," as opposed to offline, "in classes for example ... it's like a robot that's sent off, that's not really me." Online platforms thus mediated Nuun's alienation because they allowed them to elaborate/articulate themselves otherwise: "I was read as a boy and I partook in that." This active partaking in a construction of a self marks a shift in the ways in which queers enter self-other relations, usually negating; and yet now by re-orienting that self towards queerness (and other queers), an affirmation occurs through the very re-negotiation of relational terms offered by the queer internet spaces in which they interacted. This yearning for recognition and reconciliation was echoed by the other individuals I worked with for this paper, all emphasizing the gradual negotiation and understanding of oneself through the affirmation offered by, at times, just the existence of other queers.

For Malak, this is a problem of "exposure." Though, for example, she possessed a knowledge of her attraction to other women, it was always an ambiguous one. She notes, however, that in the meeting of "different groups in the community," this attraction was affirmed with the aid of "an other familiarity ... " Even at a discursive lePel, Malak has entered a register wherein she can make reference to this "community" within which she locates herself, however tenuously. Socially, mutual recognition mediates a rift that occurs between the queer individual and themself, and between them and other people/the world. Put differently, between inside and inside, and inside and outside, revealing the relationship between the two to be more porous and dialectical than these concepts allow. This sort of relationality, or queer connectivity, works to heal individuals saturated in and by heterosexuality which fragments queers in such similar ways as to make the experience of "living a double life" a universal paradigmatic feature of a shared/collective "queer life." In speaking to this fragmentation, Malak distinguishes between the calculated and paranoid self-fashioning that contributes to her feelings of individualization and alienation, and the freedom of a directed self-fashioning that is aimed at the excavation of affirmative potentials when with other queers. The directional or intentional nature of this

1 "I discovered something within myself that was both new and old" 
self-fashioning is one that, for her, is exemplified in what queers are best at - "spotting" other queers. For Malak, the combination of signifiers and context marks certain individuals as recognizably queer, opening up a concealed desire to reach out to them as they are presumably reaching out to you. Malak describes this form of signification as "making a statement ... letting people like me know that I am like this." This desiring of oneself through others, I believe, constitutes an active and affirmative occupation of one's body (which is marked) by re-signifying it in queer terms, for queer purposes.

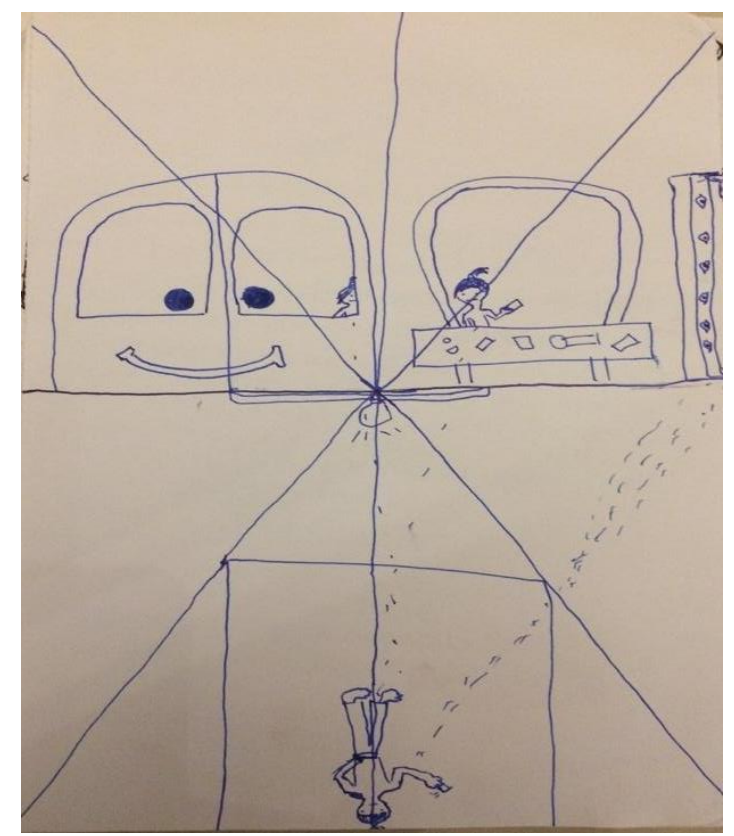

In an effort to understand the transitions between these two modes, Malak points me to her home as a nexus of pain. In the drawing, Malak dissimulates the bedroom as "private" space, "ما في حاجة عندنا اسمها

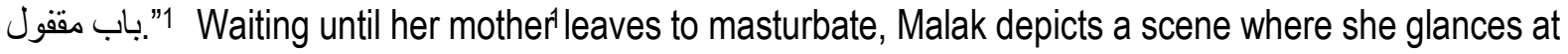
her reflections in the mirrors on her dresser and closet staring back at her. Emphasizing her position within the physical layout of the room, the lines divide Malak along with the space. The bedroom itself sustains an illusion of privacy, individualism, and autonomy that are integral to the coherence of a subject that wakes up every day, stands before their closet to make a decision about how they will be seen, and goes off to be productive. Malak is, however, keenly aware of her precarious access to this illusive and illusory autonomy, pointing to the ways in which she is, as many queers articulate, infantilized by the militarized paternalism that characterizes both "public" and "private" spaces in Egypt. The door is indeed always open, and the innermost intimacies of queer individuals are precisely what get to be exploited by authoritarian heterosexuality. Once more, it is the space (conceptual and material) of the closet which naturalizes it, by presupposing the subject that will stand before it, indeed even offering them a place to deposit their "dirty little secret," since the world beyond this closet produces it necessarily as such. The fragmented reflections in Malak's drawing punctuate the split that she embodies as a queer - which, to her, gains its meaning precisely from the intersections of her marginalization. Queerness as she was introduced to it is "a radical inclusivity" that, in its non-specificity, offered the promise of a wholeness that could be achieved with other queers and with oneself. This fragmentation of her in the drawing then alludes to the way in which something of an authentic Malak is both caught up in and birthed out of these

1 "At home, we don't have the Eoncept of a closed door" 
intersections. Malak too here becomes a nexus of power relations of which she is no longer a passive recipient. She finds ways to make due, as all queers must. Our entanglement in and constitution by violence then charges us in varied ways that are difficult to pin down or ascertain at the outset. But we are charged nonetheless with that ambiguous potential that we, with other queers, learn to channel, direct, and hone for the purpose of conducting the terms of our violation.

On a final note, it seems that queerness is always closeted/closed off by heterosexuality, that the closet is indeed heterosexual because it conceals and naturalizes a topography of power that it itself presupposes in order to legitimize its claims to originality. In this paper I have attempted to explore the conditions of possibility of a divide between in-private/out-public to show that such a divide is indeed an effect of power. By positing a public, one must presuppose a protector of this public, ushering in the state as benefactor. This becomes the realm of politics. The private then gets to be defined oppositionally as apolitical, obscuring the insidious ways in which this realm is, too, a site for the inscription of power. Ideology is naturalized as feelings of shame, guilt, etc., despite them being techniques of discipline and subjection - insofar as they are formed in response to fears of social exclusion, legal punishment, or divine retribution. In spite of these overwhelming efforts to quell it, however, queerness emerges and connects isolated nodes, offering queers, their meeting itself a self-sustaining and troubling act, an opportunity to collectivize in radical ways.

\author{
lover, we were never meant to find each other \\ lover, we were kept from one another, lover \\ lay down your arms, let's bind each other \\ in the rubble, we can mother \\ futures, lover, future-lovers \\ we can fight todays together
}




\section{References}

AbuKhalil, A. A. (1997). Gender boundaries and sexual categories in the Arab world. Gender Issues, 15(1-2), 91.

Butler, J. (1997). Gender is burning: Questions of appropriation and subversion. Cultural Politics 11, 381395.

Fanon, F. (1970). Black skin, white masks. London: Paladin.

Halberstam, J. (2005). In a queer time and place: Transgender bodies, subcultural lives (Vol. 3). NYU press.

Lugones, M. (2007). Heterosexualism and the colonial/modern gender system. Hypatia, 22(1), 186-219.

Mikdashi, M., \& Puar, J. K. (2016). Queer theory and permanent war. GLQ: A Journal of Lesbian and Gay Studies, 22(2), 215-222.

Muñoz, J. E. (1999). Disidentifications: Queers of color and the performance of politics (Vol. 2). U of Minnesota Press.

Muñoz, J. E. (2011). Cruising utopia: The then and there of queer futurity. NYU Press.

Pratt, N. (2007). The Queen Boat case in Egypt: sexuality, national security and state sovereignty. Review of International Studies, 33(1), 129-144.

Rao, R. (2014). The locations of homophobia. London Review of International Law, 2(2), 169-199.

Sullivan, N. (2003). A critical introduction to queer theory. NYU Press.

Wittig, M. (1992). The straight mind and other essays. Beacon Press. 